\title{
BIMBINGAN KEISLAMAN ORANG TUA TERHADAP REMAJA DALAM MENGHADAPI PANDEMIK COVID 19
}

\author{
Nurhasanah \\ Sekolah Tinggi Ilmu Tarbiyah Sunan Giri Kota Bima \\ Nur.hasanah100194599@gmail.com
}

Eka Mei Ratnasari

Institut Agama Islam Negeri Metro Lampung

Ekameiratnasari1@gmail.com

\begin{abstract}
Based on the results of the study, it is known that the anxiety level of adolescents during the Covid-19 pandemic is in the high category. This situation must be reduced by providing various counseling services so that the adolescent's anxiety level can be reduced. Services that can be provided to adolescents to reduce anxiety levels during the Covid-19 pandemic are individual counseling services, group guidance and counseling and Islamic-based parental guidance. Parents as the closest educators of children play an important role in bringing children closer to Islamic teachings in the face of the Covid - 19 pandemic.
\end{abstract}

Keywords: Islamic Guidance; Parents; Covid Pandemic 19 


\section{A. Pendahuluan}

Selama dalam masa normal kehidupan manusia, jarang ada ancaman penyakit yang mampu menguasasi begitu banyak kepala manusia secara massal. Selama berminggu minggu, hampir semua surat kabar menampilkan cerita informasi seputar pademi virus Corona Disease atau dikenal Covid-19 di halaman depan dan menjadikannya topic pembahasan di berbagai sudut kota. Program radio dan tv menyiarkan kabar tentang para korban penyintas Covid 19, dan tergantung pada apa yang paling di minati plattfrom media sosial di penuhi dengan statistic yang menakutkan, saran praktis atau humor yang kuat tentang pendemi ini.

Seperti yang telah di laporkan terkait dengan pandemic ini, bombardier informasi yang terus menerus ini dapat mengakibatkan peningkatkan, kecemasan, dengan efek langsung pada kesehatan mental umat manusia, terutama terhadap remaja ${ }^{1}$. Remaja merupakan salah satu generasi muda yang sangat rentan dan memerlukan bimbingan kejalan yang baik agar remaja tidak salah jalan yang yang bisa merugikan diri sendiri yang bahkan bisa mempengaruhi mental remaja ${ }^{2}$. Remaja harus di bekali dengan ilmu pendidikan agama Islam yang bisa memegang peranan penting dalam membentuk kepribadian remaja, dengan menanamkan pendidikan agama Islam remaja dapat mengendalikan hawa nafsunya, emosional, temperamental dan mengarahkan pada perbuatan yang baik serta dapat memecahkan masalah masalah yang terjadi dalam kehidupan remaja, baik dengan teman sebaya, masyarakat atau yang ada keterkaitan batin antara diri nya dengan allah SWT.

Kategori remaja adalah dalam batasan usia pada umumnya anak anak yang berusia 12 tahun sampai dengan 19 tahun sedang dalam pertumbuhan yang mengalami masa remaja (Remaja

1 Khoirul Bariyyah Hidayati dan . M Farid, "Konsep Diri, Adversity Quotient dan Penyesuaian Diri pada Remaja," Persona:Jurnal Psikologi Indonesia 5, no. 02 (20 Mei 2016), https:// doi.org/10.30996/persona.v5i02.730.

${ }^{2}$ Lis Binti Muawanah, "KEMATANGAN EMOSI, KONSEP DIRI DAN KENAKALAN REMAJA," Persona:Jurnal Psikologi Indonesia 1, no. 1 (1 Juni 2012), https://doi.org/10.30996/persona.v1i1.9. 
Awal) ${ }^{3}$. Masa remaja termasuk masa yang sangat menentukan dimana pada masa ini, remaja banyak mengalami perubahan pada psikis dan fisiknya. Remaja sekarang ini di hadapkan pada lingkungan yang tidak begitu stabil yang berpotensi untuk mempengaruhi perkembangan dalam setiap fasenya, khusunya dalam membentuk kepribadiannya.

Secara psikologis, masa remaja di anggap sebagai periode "Badai dan Tekanan" suatu masa dimana ketegangan emosi meninggi sebagai akibat dari perubahan fisik dan kelenjar secara biologis. Karena pada dasarnya di usia remaja timbul keinginan untuk di hargai, di perhatikan dan di terima oleh teman teman nya. Akibat dari kenakalan remaja tersebut, biasanya bagi remaja yang masih sekolah dapat beresiko di keluarkan dari sekolah, cacat seumur hidup atau meninggal karna kebut-kebutan dan tawuran dan di penjara karena tindakan criminal. Remaja yang sering berperilaku buruk di lingkungan sekolah, membolos sekolah saat KBM berjalan, tawuran (berkelahi) antar pelajar, kebut kebutan berkendaraan, merokok, mabuk-mabukan, kecanduan obat dan sebagainya adalah sama dengan menjatuhkan diri sendiri kea rah kehancuran.

Gangguan masalah remaja tersebut sebagai childhood dissorder dan menimbulkan penderitaan emosional minor serta gangguan kejiwaan lain pada pelakunya ${ }^{4}$. Kejahatan yang di lakukan oleh remaja intinya berasal dari kondisi masyarakatnya dengan segala segi pergolakan sosial yang ada di dalamnya ${ }^{5}$. Kejahatan remaja sering di sebut sebagai salah satu penyakit masyarakat atau penyakit social sehingga cenderung membutuhkan bimbingan. Bimbingan adalah proses pemberian bantuan baik terhadap remaja maupun kelompok menggunakan cara cara psikologi agar yang remaja yang bersangkutan dapat keluar dari masalah nya dengan kekuatan sendiri, baik bersifat preventif, kuratif, korektif maupun development. Remaja

${ }^{3}$ Syamsu Yusuf, Psikologi perkembangan anak dan remaja (Bandung, Indonesia: PT Remaja Rosdakaryam, 2011).

${ }^{4}$ Affan Yusra, Dwi Yuwono Puji Sugiharto, dan Anwar Sutoyo, "Model Bimbingan Belajar Berbasis Prinsip-prinsip Belajar dalam Islam untuk Meningkatkan Kemanfaatan Ilmu," 2017, 7.

5 Okta Diferiansyah, Tendry Septa, dan Rika Lisiswanti, “Gangguan Cemas Menyeluruh," t.t., 6. 
merupakan salah satu bagian dari unsure masyarakat yang paling membutuhkan pembinaan mental, moral dan ketakwaan kepada Allah SWT ${ }^{6}$.

Bimbingan terhadap remaja merupakan hal paling substansi saat ini. Dimana dunia sedang di landa pandemic yang cukup mengkhawatirkan, yaitu munculnya virus Corona Disease atau dikenal juga sebagai Covid-19. Hampir semua Negara di dunia ini mengalami maslaah besara dengan kehadiran pandemic Covid-19 ini, tidak terkecuali Indonesia. Covid-19 adalah jenis virus baru yang di temukan pada tahun 2019 dan belum pernah di identifikasi menyerang manusia sebelumnya oleh Word Health Organization ${ }^{7}$. Covid 19 merupakan penyakit menular yang di sebabkan oleh syndrome pernapasan akut corona virus 2 (severe acute respiratory syndromr corona virus 2 aatu $S A R-C o V-2)^{8}$

Penularan Covid-19 yang sangat cepat sehingga membuat organisasi kesehatan dunia World Healthy Organization (WHO) menetapkan virus corona sebagai pandemic pada 11 Maret 2020. Status pandemic atau epidemic global manandakan bahwa penyebaran Covid-19 berlangsung sangat cepat. Beberapa langkah cepat dilakukan oleh pemerintah agar virus corona ini tidak menular dengan cepat seperti menerapkan Work From Home (WFH), Social Distancing dan lain lain'. Masyarakat juga di edukasi untuk menerapkan pola hidup sehat dengan mencuci tangan dengan sabun sesering mungkin, memakai masker ketika berpergian keluar rumah, serta menjaga jarak. Kondisi yang dating tiba-tiba ini membuat masyarakat tidak siap menghadapinya baik secara fisik ataupun psikis. Di antata

${ }^{6}$ Muzdalifah M Rahman, “Upaya Orang Tua dalam Membimbing Remaja" 6, no. 1 (2015): 22.

7 Binti Muawanah, "KEMATANGAN EMOSI, KONSEP DIRI DAN KENAKALAN REMAJA."

${ }^{8}$ Indah Lestari, "MENINGKATKAN KEMATANGAN KARIR REMAJA MELALUI BIMBINGAN KARIR BERBASIS LIFE SKILLS” 3, no. 1 (2017): 11. Menyeluruh."

9 Diferiansyah, Septa, dan Lisiswanti, "Gangguan Cemas 
konsdisi psikologis yang di alami oleh masyarakat adalah rasa anxiety apabila tertular ${ }^{10}$.

Menurut American Psychological Association (APA) kecemasan merupakan keadaan emosi yang muncul saat individu sedang setres, dan di tandai oleh perasaan tegang, pikiran yang membuat individu merasa khawatir dan di sertai respon fisik (Jantung berdetak kencang, naiknya tekanan darah dan lain sebagainya ${ }^{11}$. Anxienty merupakan bentuk ketidak beranian di tambah keseriusan terhadap hal hal yang tidak jelas. Anxiety merupakan perasaan takut yang tidak jelas objek nya dan tidak jelas pula alasan nya. Anxiety ini juga di alami oleh para remaja, karena usia remaja dapat di katakana usia yang masih labil dalam menghadapi kondisi kondisi yang tidak terduga $^{12}$. Kondisi emosi remaja akan mudah terguncang seperti, Anxiety yang berlebihan, ketakutan akan tertular virus ini dan sebagainya. Penelitian ini mengungkap tentang kondisi anxiety yang di alami oleh remaja pada masa pandemic covid 19.

\section{B. Metode penelitian}

Metode yang di gunakan dalam penelitian ini adalah kuantitatif deskriptif. Sampel penelitian ini adalah 139 remaja, sengan menggunakan teknik purposive, random sampling. Purposive sampling adalah salah satu teknik sampling non random sampling dimana peneliti menentukan pengambilan sampel dengan cara menetapkan ciri - ciri khusus yang sesuai dengan tujuan penelitian sehingga di harapkan dapat menjawab permasalahan penelitian.

Berdasarkan penjelasan purposive sampling tersebut, ada dua hal yang sangat penting dalam menggunakan teknik sampling. Yaitu non random sampling dan menetapkan cirri khusus sesuai tujuan penelitian oleh peneliti itu sendiri.

${ }^{10}$ Hilda Vildayanti, Irma Melyani Puspitasari, dan Rano Kurnia Sinuraya, "REVIEW: FARMAKOTERAPI GANGGUAN ANXIETAS" 16 (t.t.): 18 .

${ }^{11}$ Intan Puspitasari dan Dewi Eko Wati, "STRATEGI PARENTSCHOOL PARTNERSHIP: UPAYA PREVENTIF SEPARATION ANXIETY DISORDER PADA ANAK USIA DINI," no. 1 (2018): 12.

12 Binti Muawanah, "KEMATANGAN EMOSI, KONSEP DIRI DAN KENAKALAN REMAJA." 
Instrument yang di gunakan adalah skala kecemasan remaja. Analisis data menggunakan analisis deskriptif

\section{Pembahasan dan Hasil}

\section{Remaja}

Siapapun yang memiliki anak remaja pasti merasakan betapa susah nya memahami mereka. Wajar saja, remaja mengalami proses perubahan perilaku dan pola pikir yang awalnya kekanakan menjadi lebih dewasa. Perilaku tersebut adalah semua aktivitas remaja baik yang dapat maupun yang tidak dapat di amati, sementara pola pikir adalah cara menilai dan memberikan kesimpulan terhadap sesuatu berdasarkan sudut pandang tertentu. Anak-anak secara konkret, remaja berfikir lebih abstrak, dan orang dewasa berfikir lebih filosofis, berfikir jauh kedepan, sertas dapat melihat dari berbagai sudut pandang . perilaku dan pola pikir inilah yang akan membentuk karakter seorang remaja ${ }^{13}$.

Perilaku dan pola pikir anak mendadak berubah saat remaja akibat factor internal dan eksternal . factor eksternal adalah lingkungan, pergaulan, serta rollemodel sementara factor internal terkait dengan perkembangan otak dan hormone. Sering kali masyarakat menyalahkan factor hormonal sebagai penyebab perubahan perilaku dan pola pikir remaja. Banyak orang tua yang belum memahami bahwa perubahan perilaku dan pola pikir remaja sebenarnya di sebabkan oleh perkembangan otaknya $^{14}$.

Otak manusia senantiasa berkembang untuk beradaptasi. Saat remaja, bagian otak yang berfungsi dalam pengambilan keputusan belum berkembang sempurna. Bagian tersebut adalah lobus frontal (Pre Frontal Cortexs) yang terletak di belakang dahi ${ }^{15}$. Selain berfungsi dalam pengambilan keputusan, lobus frontal

${ }^{13}$ Zaenal Abidin, "Layanan Bimbingan Belajar sebagai Upaya Peningkatan Kualitas Proses Belajar Mengajar" 11, no. 1 (t.t.): 12.

14 Raka Yusuf, Harni Kusniyati, dan Yurike Nuramelia, "APLIKASI DIAGNOSIS GANGGUAN KECEMASAN MENGGUNAKAN METODE FORWARD CHAINING BERBASIS WEB DENGAN PHP DAN," Jurnal Sistem Informasi, 2016, 13.

${ }^{15}$ Bariyyah Hidayati dan ., "Konsep Diri, Adversity Quotient dan Penyesuaian Diri pada Remaja." 
juga mengatur perencanaan, spontanitas, konsenkuensi, pemecahan masalah, empati, serta perilaku sosial dan seksual. Karena otak berkembang dari belakang kedepan, maka lobus frontal menjadi bagian otak yang terakhir berkembang sempurna, yaitu ketika seorang berada berusia 25 tahun. Padahal usia dewasa menurut undnag-undang maupun yang berlaku umum dalam masyarakat adalah usia 18 tahun $^{16}$.

Perkembangan lobus frontal pada remaja ternyata kalah cepat dengan system limbic, yaitu bagian otak yang mengatur emosi, motivasi, dan perilaku. Jika di ibaratkan sebagai manusia, system limbic memiliki karakter emosional dan berani mengambil resiko. Sementara, lobus frontal ibarat orang yang tenang, logis, focus. Itulah mengapa remaja cenderung impulsive, tidak memikirkan konsenkuensi dari perbuatan nya, dan suka hal menantang ${ }^{17}$.

Satu lagi, otak remaja memiliki bagian bernama striatum yang mengatur tentang penghargaan (Reweard System). Di bandingkan dengan anak anak dan orang dewasa, streatum pada otak remaja merespon penghargaan lebih cepat dan lebih akurat. Misalnya, saat remaja menerima uang, streatum nya menunjukan aktivitas tinggi. Pada percobaan yang di lakukan oleh Professor Adriana Galvan dari University Of California, striatum remaja ternyata membuat mereka lebih berani mengambil resiko di bandinghkan orang dewasa ${ }^{18}$. Selain itu, remaja memiliki tingkat kegembiraan yang lebih tinggi dibandingkan orang dewasa, meskipun mereka menerima uang dengan jumlah yang sama.

Striatum tidak hanya merespon penghargaan berupa uang, namun juga makanan, ujian, dan respon positif dari lingkungan sekitar. Sayangnya, remaja dengan striatum yang kuat memiliki kecenderungan untuk melakukan perilaku berisiko dan menikmatinya.

16 Acen Dores, “Konsep Bimbingan Konseling Islam dalam Mengatasi Remaja Terjerumus Dalam Perilaku Homoseksual” 5 (2016): 10.

${ }^{17}$ Rahman, "Upaya Orang Tua dalam Membimbing Remaja."

${ }^{18}$ Yusuf, Psikologi perkembangan anak dan remaja. 


\section{Bimbingan Orang Tua}

Orang tua adalah orang yang paling dekat hubungan kekerabatan dengan remaja. Tetapi banyak di temukan fakta di lapangan bahwa antara orang tua dan remaja seeking kali berbeda pandangan, seringkali mereka lebih mementingkan teman bermain daripada kepentingan orang tua atau keluarganya. Hal ini di karenakan kurang nya komunikasi dari hati ke hati antara remaja dengan orang tuanya. Kompleksitas yang tergambar di penjelasan di atas tentunya memerlukan kesiapan dan kemantapan dari individu sebagai orang tua, karena ketika anak berada dalam posisi rentan terutama masa remaja maka tempat mengadu dan bertanya adalah kepada orang tua mereka, dan merupakan kewajiban dari orang tua untuk menjawab dan menyelesaikan masalah anak tersebut.

Hubungan antara orang tua dengan anak adalah hubungan yang bersifat dan memang terjalin secara alamiah, dilaksanakan dalam bentuk dalam kasih sayang yang murni, rasa kasih sayang antara orang tua dengan anak nya. Rasa kasih sayang tersebut memberi refleksi terhadap pemenuhan kebutuhan pendidikan anak $^{19}$. Berbicara tentang kewajiban dari orang tua memang sangatlah berat karena anak adalah titipan dari allah SWT, penting nya peranan orang tua memiliki karakter yang baik merupakan hal yang hamper mutlak di miliki agar anak dapat memperoleh pendidikan yang baik.

Tugas utama dari keluarga bagi pendidikan anak ialah merupakan peletak dasar bagi pendidikan akhlak dan pandangan hidup keagamaan ${ }^{20}$. Sifat dan tabiat anak sebagian besar di ambil dari kedua orang tua nya dan dari anggota keluarga nya yang lain. Pendidikan dan pemahaman yang di berikan oleh orang tua tentunya harus memiliki kepribadian yang unggul di samping memiliki pengetahuan yang cukup baik dari segi pendidikan formal, teknologi, informasi dan yang terpenting pemahaman agama, untuk itu ada beberapa unsure

19 H. Abu Ahmadi Munawar Sholeh, Psikologi Perkembangan (Jakarta: Rinneka Cipta, 1991).

20 Jalaluddin Rakhmat, Psikologi Agama: Sebuah Pengantar (Bandung: Mizan, 2004). 
pokok yang harus di penuhi untuk memaksimalkan peran orang tua agar dapat mendidik remaja yakni :

a) Memiliki pengetahuan agama yang baik mempersiapkan anak menjadi manusia yang unggul merupakan tugas utama dan paling berperan dalam pembentukan karakter anak dan kesiapan mereka dalam menyongsong kehidupan, tugas tersebut tidaklah gampang dan tentunya yang utama di berikan adalah pendidikan akhlak dan moral kesemuanya itu bisa di dasarkan pada pemenuhan pendidikan dan pengetahuan agama yang baik. Rasullah SAW juga menegaskan bahwa misi utamanya dalam mendidik manusia adalah untuk mengupayakan pembentukan karakter yang baik (good character)

b) Berwawasan luas. Perkembangan teknologi dan informasi di zaman modern ini merupakan hal yang tidak dapat di bendung karena hal tersebut sudah merupakan kebutuhan yang mendasar bagi semua kalangan, untuk itu menjadi orang tua juga harus memiliki pengetahuan di bidang yang luas tidak hanya dalam masalah agama namun juga harus memiliki pendidikan formal yang memadai di samping juga harus saling bisa bekerja sama dan mengerti hak masing masing.

Orang tua harus berusaha agar apa yang merupakan kewajiban anak anak dapat di kenal dan di laksanakan sesuai dengan kemampuan mereka dan kemampuan orang tua. Jika hal ini dapat kita kerjakan, maka konflik dan frustasi pada kedua belah pihak dapat di hindarkan atau paling sedikit di selesaikan $^{21}$. Peranan orang tua dapat di terapkan pada hal hal berikut ini ${ }^{22}$ :

\section{a. Children Learn What They Live}

Hendaknya orang tua berusaha menjadi contoh kepribadian yang hidup atas nilai nilai yang tinggi, dan hendak nya kehidupan keluarga "condusive" yang membantu pembentukan kepribadian kepribadian yang positif.

${ }^{21}$ Binti Muawanah, "KEMATANGAN EMOSI, KONSEP DIRI DAN KENAKALAN REMAJA."

${ }^{22}$ Yusuf, Psikologi perkembangan anak dan remaja. 


\section{b. Prestasi belajar}

Kebiasaan belajar yang baik disiplin harus sedini mungkin di tanamkan karena kedua hal ini secara mutlak harus di miliki anak anak kita kebutuhan untuk berprestasi tinggi ${ }^{23}$. Hal tersebut harus sesegera mungkin di tanamkan pada diri anak dengan jalan mengekspos mereka pada "standar of excellen" karena hanya dengan belajar yang baik dan disiplin diri yang tinggi dapat mengembangkan jiwa dan sikap "entrepreneur" kepribadian yang mau bekerja keras serta berani menghadapi kesulitan dan jika perlu kesalahan, demi keberhasilan proyek proyek yang besar.

\section{c. Kegemaran membaca}

Untuk membina kebenaran membaca, hendaknya kita sendiri menunjukan kegemaran itu, misalnya: dengan membaca surat kabar setiap pagi, buku majalah yang bermutu kemudian mendiskusikan nya.

\section{d. Makan bersama}

Makan bersama hendaknya di jadikan suatu peristiwa atau kebiasaan yang menyenangkan, yang di tunggu tunggu oleh seluruh keluarga. Makan bersama ini hendak nya merupakan satu-satunya kesempatan yang dapat di gunakan anak untuk dengan bebas dan secara spontan menceritakan pengalaman pengalamannya disekolah, di jalanan dan dengan teman temannya, orang tua hendaknya mau belajar mendengar segala curahan hati anaknya.

\section{e. Hobby}

Jika kita menghendaki anak anak kita mempunyai hobi, hendaknya kita membantu mereka dalam melaksanakan hobi tersebut, sehingga hobi itu benar benar berkembang. Hendaknya orang tua memberikan kebebasan kepada anak untuk berada bersama sama dengan teman-teman. Jika hubungan orang tua dan anak bersifat terbuka, di nada banyak pengertian dan inteese pada pihak orang tua, tidak

23 Ignatius Gemilau Ragil Prasetya, "BIMBINGAN BELAJAR EFEKTIF UNTUK MENINGKATKAN KEBIASAAN BELAJARPADA SISWA KELAS VII" 2, no. 1 (2013): 4. 
perlu orang tua merasa terlalu khawatir akan terjadi hal hal yang tidak di inginkan.

\section{f. Memberikan Kepercayaan}

Remaja bukan lagi anak anak orang tua hendaknya memberikan kebebasan untuk, dalam hal hal tertentu, mengambil keputusan atas tanggung jawab sendiri.

\section{g. Pendidikan Seks}

Dalam periode ini anak anak dan remaja kita sudah memerlukan pendidikan seks, pendidikan tersebut adalah pendidikan yang berhubungan dengan perubahan fisik dan biologis yang di alami periode ini. Kita memberikan pengertian kepada mereka, bahwa mereka harus dapat menerima, memelihara dan menghormati keadaan tubuh mereka dan bahwa perubahan perubahan ini akan menyebabkan adanya "seximpluse", suatu "dorongan diri dalam" yang belum mereka alami sebelum nya.

\section{h. Pendidikan Agama}

Dalam pendidikan agama hendaknya di usahakan agar ajaran ajaran agama tidak hanya di ketahui tetapi juga agar benar benar di fahami dan di hayati sehingga dapat menimbulkan keinginan besar untuk hidup sesuai dengan kehendak tuhan yang maha esa.

\section{i. Sikap Positif Terhadap Kerja}

Orang tua hendak nya menanamkan sikap positif terhada pekerjaan rumah tanpa menggurui sehingga anak dengan sendirinya melaksanakan pekerjaan rumah. Akhirnya bila iklim dan suasana rumah kit ahangat dan di dalam nya dapat dirasakan adanya perhatian, pengakuan, pengertian, penghargaan, kasih sayang, saling percaya dan waktu di sediakan oleh orang tua bagi anak anak. Maka mereka akan berusaha untuk hidup sesuai dengan nilai nilai yang kita junjung tinggi.

\section{Tujuan Bimbingan Keislaman}

Anak dan remaja merupakan generasi penerus dari para pendahulunya, yakni mereka menjadi bekal atau calon yang akan menggantikan tugas tugas para senior nya. Hal ini membuat 
mereka harus dipersiapkan dengan matang agar dapat menjalankan kewajibannya dengan baik ${ }^{24}$. Ada beberapa tujuan dalam bimbingan keislaman ${ }^{25}$ :

a) Memiliki nilai nilai keimanan yang kuat, yakni, mereka mempunyai pendoman atau pegangan (prinsip hidup dan agama) sehingga mereka tidak terjerumus ke hal hal yang dapat merugikan mereka (seks bebas dan narkotika).

b) Bertata karma yang baik dan berbudi luhur terhadap sesama(saling menghormati, suka menolong)

c) Belajar dengan giat dan tekun, agar segera dapat menyelesaikan studi nya dan dapat ikut serta dalam pembangunan bangsa.

d) Berprestasi, dengan ini orang lain dapat mengakui dan menghargai bakat serta kemampuan mereka.

e) Banyak membaca. Yakni membaca literatur, yang sehat dan bermutu, agar dapat memperluas horizon dan cakrawala mereka dan tidak gagap terahap ilmu pengetahuan dan teknologi sehingga mereka dapat bersaing di era globalisasi seperti ini.

f) Mempunyai hobi dan kegiatan bermanfaat untuk mengisi waktu luang di samping kegiatan belajar (menjahit, melukis) dan juga dapat menjadikan usaha untuk meningkatkan ekonomi mereka.

g) Bertanggung jawab atas setiap sesuatu yang mereka lakukan

h) Disiplin dalam setiap hal

i) Dapat membagi waktu dengan baik antara beribadah, belajar, bermain dan berkumpul bersama keluarga.

j) Dapat melaksanakan hak dan kewajiban mereka dengan seimbang.

${ }^{24}$ Yusuf, Psikologi perkembangan anak dan remaja.

25 Yusra, Sugiharto, dan Sutoyo, "Model Bimbingan Belajar Berbasis Prinsip-prinsip Belajar dalam Islam untuk Meningkatkan Kemanfaatan Ilmu." 


\section{Hasil Penelitian}

Hasil analisis deskriptif data penelitian tentang kecemasan berlebihan (anxienty) yang di alami remaja Kelurahan Santi, Kecamatan Raba Kota Bima - NTB pada masa pandemic COVID19 di jelaskan pada table berikut ini:

\begin{tabular}{|c|c|c|c|}
\hline Kategori & Interval & F & \% \\
\hline Rendah & $<12$ & 3 & 2,1 \\
\hline Sedang & $12>X<24$ & 61 & 43,9 \\
\hline Tinggi & $24-35$ & 75 & 54 \\
\hline
\end{tabular}

Berdasarkan table di atas dapat di ketahui bahwa tingkat anxiety remaja pada masa pandemic berada pada kategori rendah sebesar 2,1\% kategori sedang yaitu 43,9\% dan kategori tinggi $54 \%$.

Hasil penelitian penelitian menyatakan bahwa tingkat anxiety remaja $54 \%$ berada pada kategori tinggi ${ }^{26}$. Hal ini kemungkinan besar di sebabkan karena kurangnya informasi yang di peroleh remaja terkait dengan pandemic Covid-19 ini yang ada pada pikiran remaja adalah virus corona sangat berbahaya yang apabila seseorang terinfeksi virus ini sulit untuk sembuh, dan kebanyakan meninggal ${ }^{27}$.

Beberapa factor yang menyebabkan anxiety pada masa pandemic Covid-19 adalah kurang nya informasi mengenai kondisi ini, pemberitaan yang terlalu hebih di media masa ataupun media sosial, kurang nya membaca literasi terkait dengan penyebaran dan antisipasi penularan Covid-19.

Dari hasil penelitian tersebut, memiliki angka dampak yang cukup tinggi. Anxiety cukup berbahaya bagi remaja karena anxiety yang di alami remaja ini akan berdampak kepada ${ }^{28}$ :

a) Kurang tidur, anxiety dapat menyebab kan insomnia dan masalah tidur lainnya semakin sedikit tidur semakin tinggi

${ }^{26}$ Lexy J Meleong, Metologi Penelitian Kualitatif (Bandung: PT Remaja Rosdakarya, 1989).

${ }_{27}$ Yusuf, Kusniyati, dan Nuramelia, “APLIKASI DIAGNOSIS GANGGUAN KECEMASAN MENGGUNAKAN METODE FORWARD CHAINING BERBASIS WEB DENGAN PHP DAN."

28 Vildayanti, Puspitasari, dan Sinuraya, "REVIEW: FARMAKOTERAPI GANGGUAN ANXIETAS." 
tingkat anxiety. Untuk mengatasi kurang tidur dapat di lakukan dengan focus pada cara cara untuk meningkatkan kualitas tidur, dengan meningkatnya kualitas tidur maka dapat mengurangi anxiety. Pertahankanlah waktu tidur yang konsisten, batasi konsumsi kopi dan alcohol, matikan alarm, olahraga, dan berjemur pada paparan sinar matahari setiap hari. Hal lain yang dapat di lakukan adalah menjaga kamar tidur tetap sejuk, gelap dan tenang, serta menjauhi gadget agar lebih cepat tidur.

b) Kesulitan untuk focus, Covid-19 telah mengancam kesehatan fisik dan psikis, dan cara hidup sehari hri. Secara tidak sengaja, setiap hari terus mendengar berbagai berita dan kemudian memikirkan cara cara untuk melindungi diri dari virus. Masalahnya adalah, selama dirumah juga harus tetap focus untuk belajar. Akibat pemberitaan Covid-19 pikiran menjadi tidak focus dan sulit berkonsentrasi pada pelajaran. Cara untuk meningkatkan konsentrasi pada masa pandemic ini adalah dengan mengurutkan apa yang mesti di lakukan, serta jangan lupa juga untuk istirahat yang cukup.

c) Sering lupa, Alexandra parpura ahli gerontology dan pendiri Aging Prespectives di Chery Chase menjelaskan bahwa anxiety dapat mempengaruhi memori. Apapun yang merilekskan tubuh akan membantu ingatan, karena relaksasi melibatkan system saraf parasimpatis. Kegiatan relaksasi yang baik seperti olahraga juga dapat merelaksasi ingatan. Melakukan permainan yang mengasah kemampuan untuk focus seperti teka teki silang, Sudoku, membuat kerajinan tangan, bermain video games, atau bermain alat music juga dapat membantu untuk mengurangi lupa ${ }^{29}$.

d) Meningkat nya iritabilitas dan mudah marah, anxiety dapat merubah emosi remaja seperti mudah marah. Anxiety yang di alami tiap orang berbeda-beda, tentu saja hal ini berkontribusi terhadap iritabilitas dan kemarahan. Penelitian menunjukan bahwa anxiety juga dapat memicu emosi ini.

29 Puspitasari dan Wati, "STRATEGI PARENT-SCHOOL PARTNERSHIP: UPAYA PREVENTIF SEPARATION ANXIETY DISORDER PADA ANAK USIA DINI." 
Kondisi anxiety yang di alami remaja pada masa pandemic ini tentu tidak bisa di biarkan begitu saja.

i. Untuk mengatasi anxiety pada remaja ini peran orang tua sangat di butuhkan, diantara nya selalu mendampingi, memotivasi, memberikan pengetahuan tentang covid19 ini. Selagu konselor atau guru bimbingan dan konseling ada beberapa hal yang dapat di lakukan untuk membantu remaja mengatasi anxiety adedalah dengan memberikan pelayanan seperti layanan konseling individual, bimbingan dan konseling kelompo. Berbagai pendekatan konseling dapat di terapkan dalam kegiatan ini. Berdasarkan beberapa penelitian menyatakan menggunakan pendekan cognitive behavioral therapy (CBT) lebih efektif untuk mengatasi kecemasan, di bandingkan pendekatan yang lain.

\section{Kesimpulan}

Berdasarkan hasil penelitian di ketahui bahwa tingkat anxiety remaja pada masa pandemic covid19 berada pada kategori tinggi. Keadaann ini harus di reduksi dengan memberikan berbagai pelayanan konseling agar tingkat anxiety remaja tersebut dapat di perkecil. Layanan yang dapat di berikan kepada remaja untuk menurunkan tingkat anxiety dalam masa pandemic covid19 adalah layanan konseling individual, bimbingan dan konseling kelompok. Orang tua memiliki peran yang sangat penting dalam memberikan bimbingan ini. Terlebih di masa pandemi banyak perubahan pola hidup yang membuat kebiasaan remaja berubah drastis.

\section{DAFTAR PUSTAKA}

Abidin, Zaenal. "Layanan Bimbingan Belajar sebagai Upaya Peningkatan Kualitas Proses Belajar Mengajar" 11, no. 1 (t.t.): 12.

Bariyyah Hidayati, Khoirul, dan . M Farid. "Konsep Diri, Adversity Quotient dan Penyesuaian Diri pada Remaja." Persona:Jurnal Psikologi Indonesia 5, no. 02 (20 Mei 2016). https://doi.org/10.30996/persona.v5i02.730.

Binti Muawanah, Lis. "KEMATANGAN EMOSI, KONSEP DIRI DAN KENAKALAN REMAJA." Persona:Jurnal Psikologi 
258 | Jurnal Bimbingan Penyuluhan Islam, Vol. 02, No. 02 Juli-Desember 2020

Indonesia 1 , no. 1 (1 Juni 2012). https://doi.org/10.30996/persona.v1i1.9.

Diferiansyah, Okta, Tendry Septa, dan Rika Lisiswanti. "Gangguan Cemas Menyeluruh," t.t., 6.

Dores, Acen. "Konsep Bimbingan Konseling Islam dalam Mengatasi Remaja Terjerumus Dalam Perilaku Homoseksual" 5 (2016): 10.

Lestari, Indah. "MENINGKATKAN KEMATANGAN KARIR REMAJA MELALUI BIMBINGAN KARIR BERBASIS LIFE SKILLS" 3, no. 1 (2017): 11.

Meleong, Lexy J. Metologi Penelitian Kualitatif. Bandung: PT Remaja Rosdakarya, 1989.

Munawar Sholeh, H. Abu Ahmadi. Psikologi Perkembangan. Jakarta: Rinneka Cipta, 1991.

Prasetya, Ignatius Gemilau Ragil. "BIMBINGAN BELAJAR EFEKTIF UNTUK MENINGKATKAN KEBIASAAN BELAJARPADA SISWA KELAS VII" 2, no. 1 (2013): 4.

Puspitasari, Intan, dan Dewi Eko Wati. "STRATEGI PARENTSCHOOL PARTNERSHIP: UPAYA PREVENTIF SEPARATION ANXIETY DISORDER PADA ANAK USIA DINI," no. 1 (2018): 12.

Rahman, Muzdalifah M. “Upaya Orang Tua dalam Membimbing Remaja" 6, no. 1 (2015): 22.

Rakhmat, Jalaluddin. Psikologi Agama: Sebuah Pengantar. Bandung: Mizan, 2004.

Vildayanti, Hilda, Irma Melyani Puspitasari, dan Rano Kurnia Sinuraya. "REVIEW: FARMAKOTERAPI GANGGUAN ANXIETAS" 16 (t.t.): 18.

Yusra, Affan, Dwi Yuwono Puji Sugiharto, dan Anwar Sutoyo. "Model Bimbingan Belajar Berbasis Prinsip-prinsip Belajar dalam Islam untuk Meningkatkan Kemanfaatan Ilmu," 2017, 7.

Yusuf, Raka, Harni Kusniyati, dan Yurike Nuramelia. “APLIKASI DIAGNOSIS GANGGUAN KECEMASAN MENGGUNAKAN METODE FORWARD CHAINING BERBASIS WEB DENGAN PHP DAN." Jurnal Sistem Informasi, 2016, 13.

Yusuf, Syamsu. Psikologi perkembangan anak dan remaja. Bandung, Indonesia: PT Remaja Rosdakaryam, 2011. 